\title{
First report of a Pliocene pike (Esocidae: Esox) in Transylvania, Romania
}

\author{
Vlad Aurel CODREA ${ }^{1}$, Nicolae TRIF $^{1,2, *}$ and Levente TOTH $^{1}$ \\ 1 Babeş-Bolyai University Cluj-Napoca, Laboratory of Paleotheriology and Quaternary Geology, 1, Kogălniceanu Str., \\ 400084 Cluj-Napoca, Romania \\ 2 Natural History Museum, Brukenthal National Museum, Sibiu; 1 Cetăţii Str., 550160 Sibiu, Romania
}

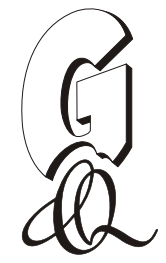

\begin{abstract}
Codrea, V.A., Trif, N., Toth, L., 2018. First report of a Pliocene pike (Esocidae: Esox) in Transylvania, Romania. Geological Quarterly, 62 (3): 644-652, doi: 10.7306/gq.1428

Pliocene fish species based on skeleton remains and associated teeth ever reported from the inner Carpathian area in Romania in the Braşov Basin (Baraolt sub-basin), which refers to a pike (Esox sp.). The fish fossils illustrating a large-sized specimen originate from the South Racos coal open pit (Racoșu de Sus, Covasna County), in the so-called "Formation with Limnocardium" (Dacian, Lower Pliocene). Comparisons with osteological material of recent pikes originating from various localities in Romania are presented. The associated mollusc fauna known from the formation that yielded the pike remains suggests the presence of a lake with a stratified water column in the Baraolt sub-basin.
\end{abstract}

Key words: fossil fish, Early Pliocene, Braşov Basin, Transylvania, Romania.

\section{INTRODUCTION}

Pliocene deposits of Romania are exposed in both inner and outer Carpathian regions. The majority of exposures is located in the Dacian Basin, either on its western (Oltenia) or northeastern (southern Moldova) sides (Andreescu et al., 2011, 2013). Besides plants and various invertebrates, the Pliocene palaeontological record includes also vertebrates (e.g., Rădulescu and Samson, 1985, 2001; Codrea, 2000; Rădulescu et al., 2003). With few exceptions, the vertebrates are mainly mammals, whereas other groups as fish, lizards and amphibians are rarely reported mainly in few old references, sometimes with doubtful assignations (e.g., presence of a "Lamna" shark in Moldova at Măluşteni, in Simionescu, 1930).

In the inner-Carpathian region, such deposits can be noticed only in more restricted areas, mainly in the Braşov Basin (southeastern Transylvania). As a result of coal mining operations carried out at the Racoşu de Sus (= Felsörakos, Covasna County) open pit over the last decade, some vertebrate fossils were recovered, e.g., few rhinoceros remains (forelimb bones and ribs) found in coal. In 2004, a nearly complete skeleton of the mastodon Anancus arvernensis (Croizet and Jobert, 1828) was unearthed (Toth et al., 2010). Close to the mastodon pelvic bones, some scattered bones (dentaries and ribs) documenting a large-sized pike were also recovered. They firstly evidence the presence of a Pliocene pike in the inner Carpathian region.

\footnotetext{
* Corresponding author, e-mail: nicolae.trif@gmail.com
}

Received: March 21, 2018; accepted: May 1, 2018; first published online: September 12, 2018

\section{GEOLOGICAL SETTING}

Racoşu de Sus is located in the Braşov sedimentary basin, the largest intra-mountain basin of the East Carpathians. It includes three smaller sub-basins, named from west to east: Bârsa-Baraolt, Sf. Gheorghe and Breţcu (Săndulescu, 1984). Among these, the westernmost Bârsa-Baraolt sub-basin (Fig. 1) is bounded by the Perşani and Baraolt mountains. The Baraolt and Cormoş rivers are crossing the basin; both are the right tributaries of the Olt River.

The basement of the Bârsa-Baraolt sub-basin is represented by the Mesozoic flysch (Lower Cretaceous: "Neocomian") of the Baraolt and Ceahlău nappes (Săndulescu et al., 1968); both are parts of the Outer Dacides (Săndulescu, 1984). To the north, these rocks are covered by the Neogene volcano-sedimentary and volcanic deposits of the Harghita Mountains (Fielitz and Seghedi, 2005; Lexa et al., 2010).

Based on molluscs and plant remains, different Miocene ages were presumed for the beginning of this sedimentation (Pontian, in Savu et al., 1978; Savu, 1981; Petrescu et al., 1987; Pannonian s. str. - "Meotian" - in Kusko, 1983), but the magnetostratigraphy (Andreescu et al., 1987) and fossil vertebrates (Rădulescu and Samson, 1985) support a Pliocene age for the basalmost sediment (Rădulescu and Samson, 1985; Andreescu et al., 1987).

Concerning the lithostratigraphic units, there are different viewpoints about the stratigraphy of this region. Savu et al. (1978) and Savu (1981) coined: (1) the basalmost "productive formation", divided into two so-called "sub-formations": a "productive" one (Pontian), overlain by the "marls with Limnocardium" (Upper Pontian); (2) the "formation of marls with ostracods" (Pliocene = Dacian-Romanian); (3) the Biborţeni Formation (Lower Pleistocene); (4) "the sedimented volcanic rocks" (Pleistocene). 


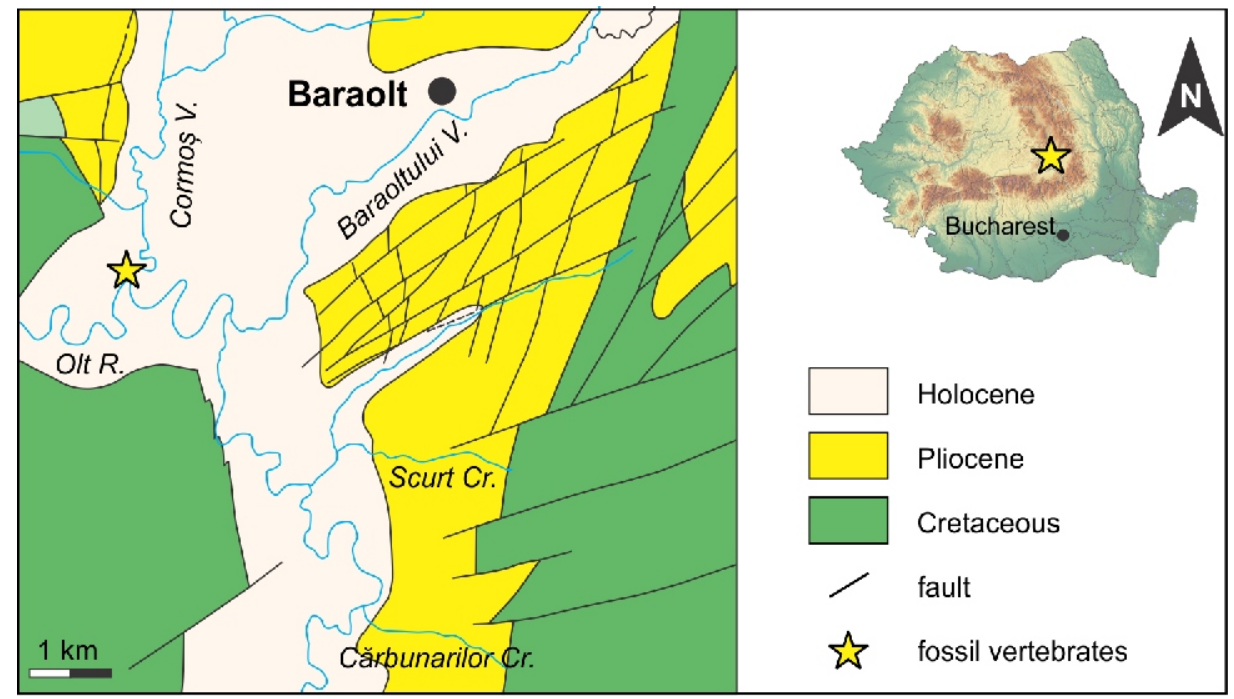

Fig. 1. Location and geology of the Baraolt sub-basin and South Racoş coal open-pit with Pliocene vertebrates

Kusko (1983) reported only three "horizons", with older geological ages: (1) "productive" (Upper Meotian-Lower Pontian); (2) "with marls" (Upper Pontian-Lower Dacian); (3) "sandy" (Upper Dacian).

Another stratigraphy of the Căpeni-Baraolt sub-basin comprises four "horizons" (Petrescu et al., 1987): (1) "productive" (bearing the coal seams I-III, Pontian); (2) "marls with Limnocardium" (bearing the coal seams IV-V; Upper Pontian); (3) "marls with ostracods" (Dacian-Romanian); (4) Biborţeni Formation (Lower Pleistocene), and (5) "volcanic rocks reworked in sediments" (Pleistocene).

It is worth to notice that Marinescu et al. (1998) presented a correlation chart for this area with two formations only: Vlăhiţa-Chirui (Pannonian s.s.-Pleistocene) and the partly coeval Baraolt Formation (Pontian-Pleistocene).

László (1999) outlined two formations in the basal section of the sedimentary succession. The lowermost one is the Vlăhiţa-Chirui Formation (including the sedimentary rocks lying under the coal seam III from the Bârsei-Baraolt sub-basin), covered by the marls of the Cormoş Formation. Based on fossil mammals, "the lower part of the sedimentary deposits in the Baraolt Basin" (i.e. Vlăhiţa-Chirui Formation) would be Upper Dacian in László (2005: 31), being in agreement with magnetobiostratigraphic data documenting rocks aged between 4.0-3.6 Ma (Andreescu et al., 1987).

The Baraolt sub-basin is also famous for coal mining that started around the mid-19th century (Papp, 1915). The initial operations in 1839 were conducted on a small scale. The first underground mine (called "Samu", near Căpeni) started to extract coal in 1872. Detailed geological survey began in 1920, with several boreholes at Căpeni, Vârghiş and Baraolt. These underground mines and open pits, once numerous, currently are at loose end. The last underground mine has been closed since over decades ago, and the last open pit at Racoşu de Sus was recently closed in 2015. It was located on the southwestern side of the sub-basin.

In the South Racoş coal open pit, the basal portion of the "productive horizon" (Savu, 1981) could be fairly observed a few years ago. It overlies the Cretaceous bedrock, ending several tens of metres above the lignite seam III in this area. In its basal part, there is a bluish-greenish clay embedding fragments of Cretaceous rocks, in a breccia-like structure. In the same level, one can also notice the presence of volcanic rocks (sand andesitic fragments, lapilli) marking volcanic activity in the Southern Harghita Mountains. It is followed by dark greyish clay-sandy rocks with interbeddings rich in snails (Helix) and painter's mussels (Unio), deposited in fluvial-lacustrine freshwater environments in a close neighbourhood of emerged land. The "productive horizon" shows large thickness variations (10 $\mathrm{m}$ at the basin margins, and $150 \mathrm{~m}$ in mid-basin areas) and bears the coal seams I (6-7 m), II (0-0.7m) and III (5-8 m).

The overlying deposits are the "marls with Limnocardium horizon" (Savu, 1981). They form a 10-100 m thick unit overlying the coal seam III, including tuff marl and clay, rich in reworked volcanic material. Just above the coal seam III, the marl contains a white-coloured lumachelle. This "horizon" is the last one exposed at South Racoş, overlain by a layer of Holocene gravels (a skull of Bos primigenius was unearthed in these rocks by one of us, L.T.) bearing numerous fossil tree trunks.

Various gravitational faults can be noticed. The major trend of the faults is $\mathrm{N}-\mathrm{S}$, controlling a plunge of deposits on distinct steps towards the basin axis. Other faults are perpendicular, but there are also few others crossing obliquely the previous ones.

The fish bones, described and illustrated hereafter, were found in the "marls with Limnocardium". The dominant rock of this unit is marl, accompanied with some conglomerates and microconglomerates, and even thin coal (lignite) seams (never of mining interest). The fish fossils occur between the coal seams III and IV.

\section{MATERIAL AND METHODS}

The herein described fossils are hosted in the collections of the Babeş-Bolyai University Paleontology-Stratigraphy Museum (abbreviated BBUPSM) in Cluj-Napoca, Romania.

The pike bones and teeth were embedded in light grey marl. The matrix rock was completely removed from the right dentary with professional mechanical gear (Airscribe W224 and W830), after reinforced by a special polymer. The left dentary was extracted partially with its ventral part fixed in the matrix rock.

The material was compared with recent bones of the Esox lucius "group" originating from five individuals of different sizes, 

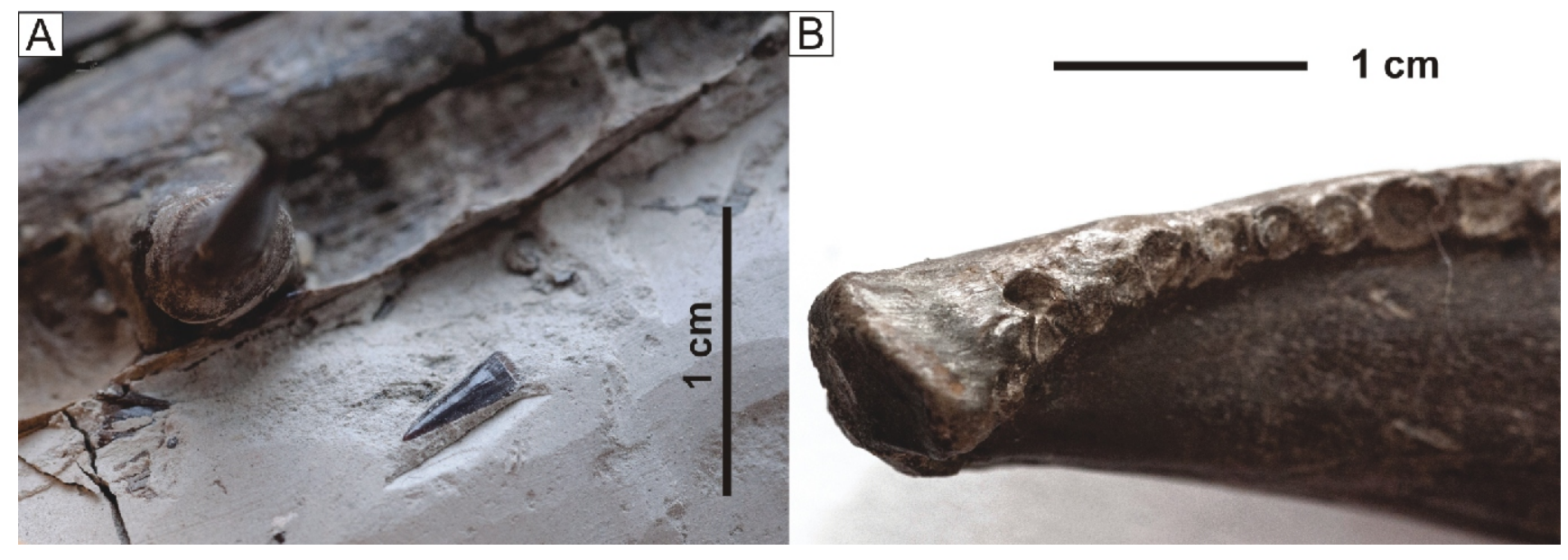

Fig. 2A - detail of the loose tooth in the matrix near the left dentary; B - detail of the right dentary symphysis

hosted in the Collection of the Natural History Museum Sibiu (abbreviated NHSM). For our viewpoint on the Esox lucius "group", see further discussions.

The measurements of the fossil bones and teeth were done on digital images, using a standard scale reference, and with the Unior calliper (model 271, measurement error of $0.02 \mathrm{~mm}$ ). The images were taken with a Nikon camera Coolpix P520 with 4.3-180 mm lens, and a Nikon D700 with $105 \mathrm{~mm}$ lens, fixed on a professional tripod. The recent reference material of Esox lucius was measured using the same calliper.

\section{SYSTEMATIC PALAEONTOLOGY}

Class: Actinopterygii Cope, 1887

Order: Esociformes Nelson, 1994

Family: Esocidae Cuvier, 1817

Genus: Esox Linnaeus, 1758

Esox sp.

M a te rial. - One isolated tooth in the rock matrix (Fig. 2A) and two dentaries': right (Figs. 2B and 3) and left (Fig. 4), most likely from the same individual, collection BBUPSM $531 \mathrm{a}$ and $\mathrm{b}$.

D e s c ription. - The right dentary is almost complete. The total length of the preserved bone is $144 \mathrm{~mm}$. The ventral process of the bone is broken, somewhere close to the middle part, while the coronoid process lacks only the distal end. The dentary is very wide at the symphysis, where it reaches $7.35 \mathrm{~mm}$ in length. The symphysis is also very tall, reaching $11.9 \mathrm{~mm}$ in ventral/dorsal measurement. It narrows down immediately in the posterior direction (to a minimum of $2.89 \mathrm{~mm}$ ), then it widens again in the middle portion of the dentary (to a maximum of $10.24 \mathrm{~mm}$ ) narrowing once again towards the coronoid process. Only one row of teeth is present along the entire dentary and it extends towards the end of the coronoid process. In the direction of the symphysis the teeth present characteristic bases of depressible teeth type. The diameter of the tooth bases increases from the symphysis towards the coronoid process. Three teeth of fixed type (ankylosed; Fink, 1981) are preserved towards the median part of the dentary. The largest tooth is situated towards the rear of the dentary, but almost equally big teeth alveoli are present in the middle part of the row. The teeth are strong, slightly curved lingually and expose visible irregular striations on the surface. A single one preserves the entire length of the crown (of $11.6 \mathrm{~mm}$ ). In dorsal view, the teeth expose oval outlines, with the longest axis in antero-posterior direction. No obvious cutting edges are present.

Unfortunately, the openings of the mandibular canal ( $\mathrm{mc}$ in Nelson, 1972) are not visible, probably due to the poor preservation. In the anterior third part of the dentary, at $20 \mathrm{~mm}$ from the symphysis, the elongated opening $(4.1 \mathrm{~mm})$ of the trigeminal nerve can be observed (tn in Fig. 3D). Numerous longitudinal and transversal cracks are crossing the bone.

The left dentary is partially encased in the original rock matrix, but most of it can be observed. The shape and size are very similar to those of the right dentary. The width of the symphysis reaches $7.42 \mathrm{~mm}$. Only one tooth of fixed type is preserved in place in the middle-posterior part of the single row of teeth. The crown height of the tooth is $10.6 \mathrm{~mm}$. On the remaining matrix, immediately next to the dentary, a small, loose, $4.6 \mathrm{~mm}$ long tooth can be found.

The order Esociformes radiated before the North America and Eurasia continents became split (Wilson et al., 1992). In the fossil record, the genus Esox has appeared since the Paleocene (Esox tiemani Wilson, 1984), but the origin of the Esociformes order can be traced even back to the Cretaceous, in the genera Estesesox and Oldmanesox (Wilson et al., 1992; Newbrey et al., 2008: 333). In the Eocene, Esox became more widespread, so it can be found in North America (Esox kronneri Grande, 1999; Lower Eocene) and in China (Esox longkouensis Chang and Zhou, 2002; Paleocene/Lower Eocene). In the Oligocene, and later on in the Miocene and Pliocene, Esox is represented by a larger number of species, but it remains restricted as before only in the Northern Hemisphere (Kovalchuk et al., 2017). This preference for the northern areas is related to the positive correlation of low temperatures and high latitudes with the longevity of this fish (Newbrey et al., 2008).

In Europe, the Esox genus is represented by Esox primaevus Gaudant, 1978, from the Lower Oligocene of Vaucluse, France; Esox sp. from the Oligocene of Switzerland (Gaudant, 1979b) and by Esox papyraceus Troschel, 1854, from the Upper Oligocene of Germany. In the Miocene, the genus is represented by Esox lepidotus Agassiz, 1844, from the Upper Miocene of Germany and by Esox sibiricus Sytchevskaya, 1974, from the Upper Miocene and Lower Pliocene of Ukraine (Kovalchuk et al., 2017). The Pliocene brought 

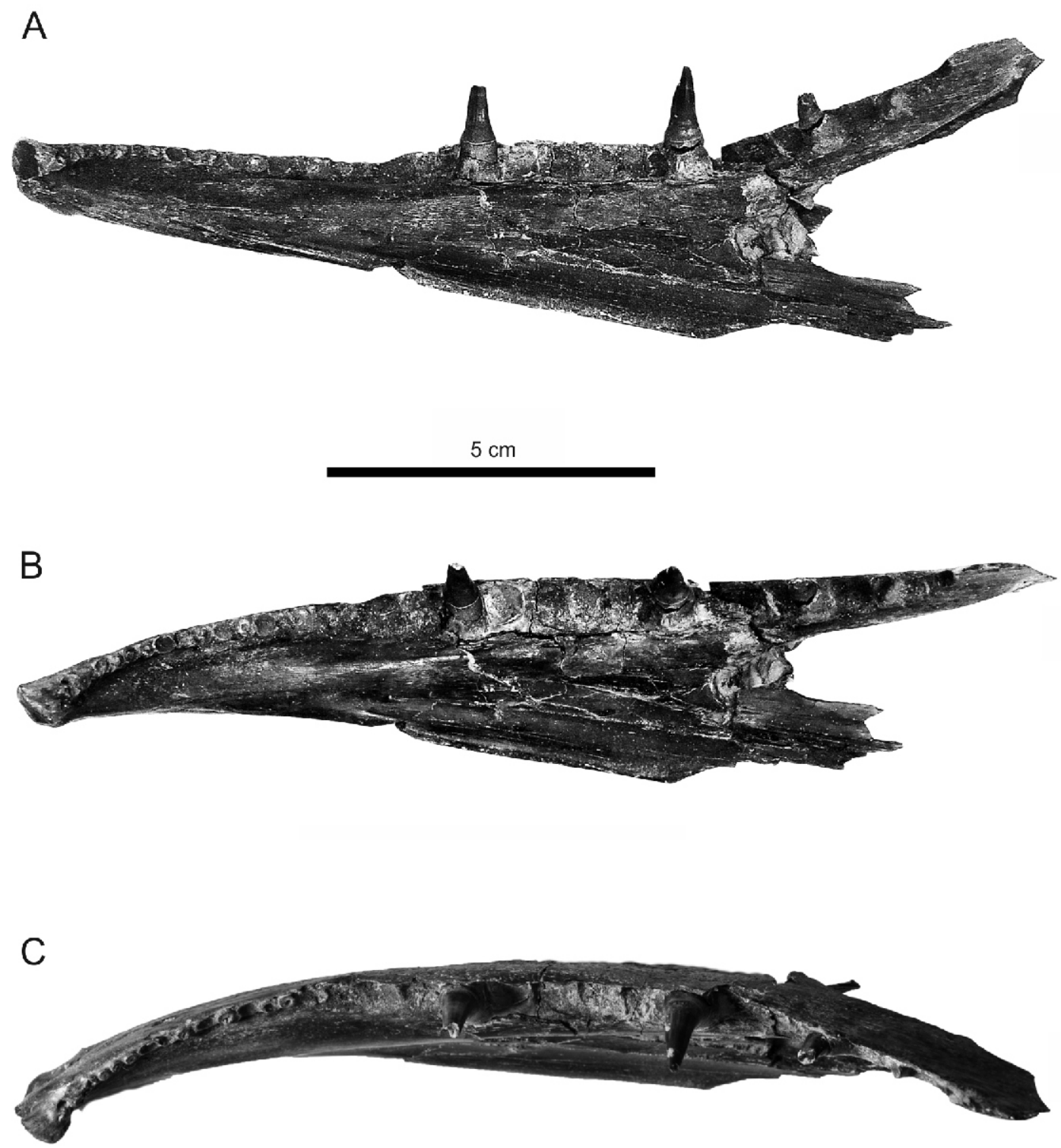

D

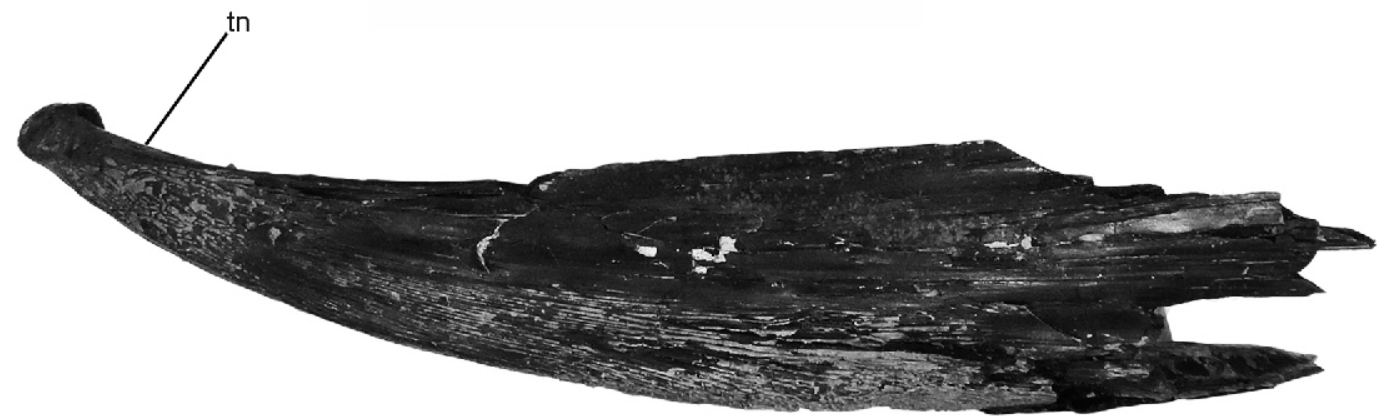

Fig. 3. BBUPSM V 531 a - Esox sp., right dentary

A - inner view; B - dorsal view; C - outer view; D - ventral view; tn - trigeminal nerve 

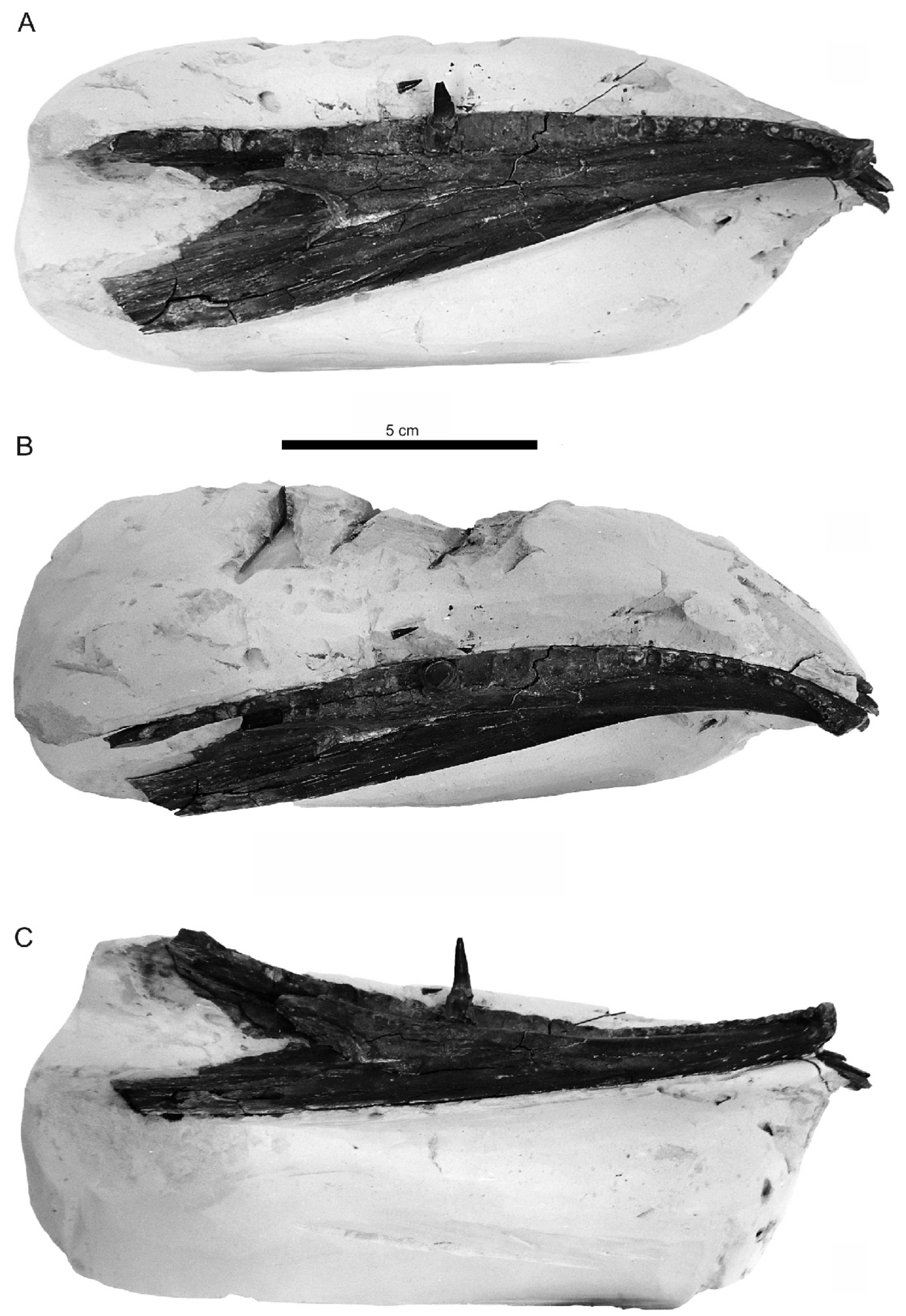

Fig. 4. BBUPSM V 531 b - Esox sp., left dentary

A - dorsal-lateral view; B - dorsal view; C - inner view 
a few more localities with Esox remains in Europe, represented by Esox moldavicus Sytchevskaya, 1974, from southwestern Ukraine, Esox sp. in the Republic of Moldova (Sytchevskaya, 1976) and Esox cf. lucius in Lower Saxony, Germany (Gaudant, 1997). The latest addition to the fossil European pikes is Esox nogaicus Kovalchuk, Wilson and Grande, 2017, from the Lower Pleistocene of Ukraine (Kovalchuk et al., 2017).

In Romania, Esox moldavicus was reported from the Oligocene (Trelea et al., 1977; Ciobanu and Zaharia, 1986, also mentioned in a list by Constantin, 1999), but the material cannot be found anymore in collections. It is unlikely that this species was really present in Oligocene marine formations. However, Esox sp. is clearly present in the Lower Pliocene (Dacian stage in Andreescu et al., 2013) of Măluşteni, on the eastern side of the Dacian Basin, southern Moldavia (Simionescu, 1930). It is also present in the Upper Pliocene (Romanian stage) of Podari locality, on the western side of the same basin (Trif et al., 2016), and it also seems to occur in the Upper Pliocene (Romanian stage = "Levantine") of Buzău (Rado and Pană, 1969). Those authors do not describe the pike remains, only mentioning the genus in text, but the drawing (Rado and Pană, 1969: plate 2, fig. 12) matches up with the general shape of an Esox tooth. Esox is also reported from the Pleistocene of the Dacian Basin (Vasile et al., 2013, 2015).

\section{DISCUSSIONS}

Compared with the recent material of E. lucius, the examined fossil Esox sp. shows a few small differences. It has a less highlighted curvature of the dentary towards its symphysis. The teeth of the recent $E$. lucius are more compressed in the labio-lingual direction and possess a well-expressed cutting edge, not found on the fossil material. The difference in labio-lingual tooth compression could be interpreted as an allometric change as preys of different sizes are approached by such large-sized specimen and the teeth need to be stronger. The dental shelf is very similar in width with the one of $E$. lucius, taking into account the difference in size of the specimens. The shape and size of the dentaries and the location of teeth types (depressible and fixed) doubtless indicate that these fossils belong to the genus Esox (Sytchevskaya, 1976).

As mentioned above, the fossils described herein were compared with the recent $E$. lucius skeletons. However, we have to underline that for the recent fish in Europe, the genus Esox currently comprises more species than previously thought. Our present view on Esox lucius is rather of a group of unclear and developing taxonomy. On this argument, we have not assigned our fossils to a certain Esox species. Another reason to avoid assignment to the species level is the very strong similarity with the sister species $E$. reichertii, to which E. lucius overlaps today in most measurements and meristic characters (Grande et al., 2004).

Based on DNA analysis it seems that the divergence of the two European related species belonging to the genus Esox, namely $E$. lucius and $E$. reichertii Dybowski 1869 , took place $\sim 4.6 \mathrm{Ma}$ (Skog et al., 2014). This age would correspond to the Dacian stage, thus to an age very close to that of our specimen. This divergence was already presumed and dated $\sim 5 \mathrm{Ma}$ by Gruzdev and Vasiliev (1988), based on fossils. They outlined that the differentiation of $E$. Iucius and $E$. reichertii based on cranial osteology can be made only with a certain probability and using also bones others than the dentary. This is another reason for which we avoid to assign the herein studied dentary material to a species. The close relation between these two species is even clearer considering that artificial hybrids are viable for at least two generations compared with other species hybrids that were not viable or had a very low viability (Crossman and Meade, 1977). After this divergence event, E. lucius was considered as a non-divergent species and all European Esox were considered by default as $E$. lucius. As consequence, the fossil material was compared many times with the single European species alive today, "son unique espèce européenne actuelle E. lucius L.” (Gaudant, 1979a: 3).

A number of works describe five species within the recent Esox genus (Crossman, 1996; Grande, 1999; Nelson, 2006; Kottelat and Freyhof, 2007). Recently, two new European Esox species were added, namely Esox cisalpinus Bianco and Delmastro, 2011 and Esox aquitanicus Denys, Dettai, Persat, Hautecoeur and Keith, 2014. The two species are distinguished based on not only DNA sequences but also external morphological characters and some skeleton characters. The new studies also show that there are reasons to believe that at least two more species will be described (Denys et al., 2014). In fact, one more species was described in 2011, namely Esox flaviae (Lucentini et al., 2011), but a new analysis shows that at the genome level the difference between Esox flaviae and Esox cisalpinus is not so clear (Gandolfi et al., 2015) and E. flaviae should be considered as a junior synonym of $E$. cisalpinus (Bertoli et al., 2016). Another study on phylogeography of $E$. lucius and $E$. reichertii also points towards the existence of more lineages of pikes in Europe than previously known (Skog et al., 2014).

In the new described species, the morphological characters, of interest also for the palaeontologists, are the number of vertebrae and a few meristic characters. However, the descriptions of the new species do not include any remarks regarding teeth, dentary, palatine or vomer bones, that are more often found in fossils.

Taking into account the discovery of the new species, we consider that dentary bones cannot be assigned to a certain species, but can be referred to the genus Esox, at least until a high-resolution study of comparative morphology is made on skeletons of all recent species of the Esox genus. The same recommendation was also done in the past (Grande, 1999) for a better understanding of the phylogeny of the order, but the progress was little or none.

High diversity within the Esox genus as a result of the recent taxonomic "splitting" of E. lucius makes us consider that the older morphological comparisons of the recent and fossil remains are lacking accuracy. The assertion of Nilsson et al. (2008: 137) that "The pike (Esox lucius L.) is an exceptionally well-studied species of fish" is invalid, at least from the taxonomical point of view.

This revision has to be approached taking into account that Esox is today regarded in any case as a species with high phenotypic variation and plasticity (Nillson et al., 2008). Also, it needs to be clarified the taxonomic status of the so-called "mutant" pikes (Lawler, 1960, 1966) and hybrids that were often described (Crossman and Buss, 1965) or created and released, viable, in the wild (Crossman and Meade, 1977).

Recent Esox representatives have a widespread circumpolar occurrence in most of the fish communities from subtropical to arctic waters (Casselman, 1996). The latitudinal distribution of pikes is correlated with the mean annual temperature, not only for the recent pikes but also for the Cenozoic species (Newbrey et al., 2008). Esox can be found in a wide variety of habitats preferring well-vegetated water bodies or flooded vegetation (Raat, 1988; Bry, 1996; Kottelat and Freyhof, 2007; Timm and Pierce, 2015). An exception seems to be E. reichertii that prefers central parts of moderately flowing rivers and lakes, with rocky bottoms (Crossman and Meade, 1977). 
A

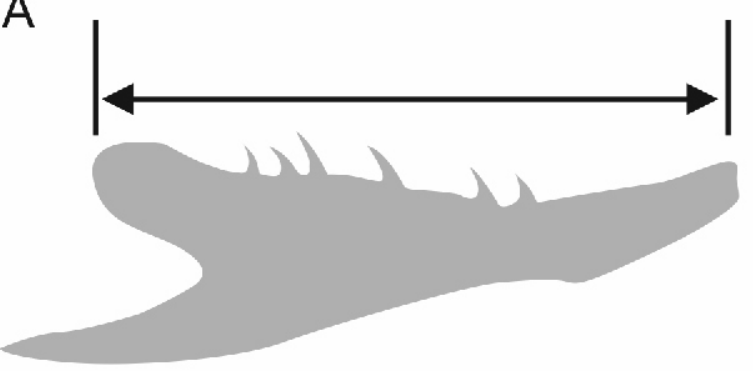

B

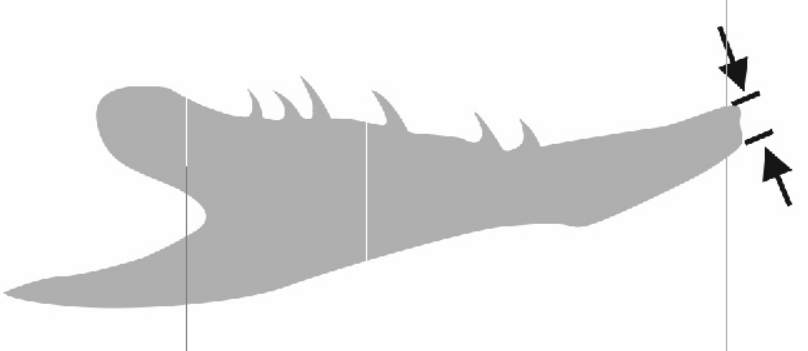

Fig. 5A - measurement of the dentary for calculation of the regression formula according to Čech et al. (2008); B - measurement of the dentary symphysis height for the calculation of Oppliger (2013) regression formula, following measure No. 4 in Morales and Rosenlund's (1979) guide

The Pliocene South Racoş regional geology is very specific. Since long time ago, with the first studies of Jekelius (1924, 1932) until Lubenescu (2005), it has been pointed to an apparent paradox recorded in the "marls with Limnocardium". It refers to the co-existence of fresh (Dreissena, Radix, Valvata, Hydrobia) and brackish water molluscs (limnocardiids, considered as endemic Upper Miocene survivors, i.e. Pontian relicts; Lubenescu, 2005). Soon after the formation of the lake, either local or more widespread swampy tendencies occurred. The presence of coal seams I-V can be plausibly explained by the occurrence of such environments. At least in the first lake stages, "anoxic low-sulphide sediments" accumulated (Marincea et al., 1997). When the Pliocene lake became deeper (i.e. "arls with Limnocardium"), this lake could presumably develop stratified waters with higher salinity in its deeper areas, possibly due to the nearby volcanic influences. Although such difference in salinity was rather low, the brackish molluscs could find there a convenient environment. In fact, the limnocardiid molluscs are salinity tolerant; the recent ones of Romania being present in both brackish and freshwater environments (Grosu, 1993). The pike also had the same salinity tolerance, as today is reported in similar environments, even in the Baltic Sea (Raat, 1988; Mann, 1996).

The pike remains were recovered from rocks documenting a nearshore area with frequent water-level changes. The emersion episodes are documented by desiccation mud cracks. The fish carcass was buried in mud just near the shore; the mastodon pelvic bones acted as a trap for the fish remains.

It is possible to make some estimation regarding the reconstructed length and weight of this Pliocene fish. We used two regression formulas for the size reconstruction (Čech et al., 2008; Oppliger, 2013) based on the dentary measurements (Fig. 4) - formulas that were devised for E. lucius. While Čech et al. (2008) uses a symphysis to the coronoid process measurement (Fig. 5A), Opplinger (2013) uses a dorso-ventral measurement of the proximal part of the dentary, corresponding with the measurement No. 4 of the Morales and Rosenlund (1979: 22) guide (Fig. 5B). For control, we verified our results on five dentaries of E. lucius originating from fish of known length, in the NHSM collection.

The control calculations revealed a medium error of the reconstructed length $<9 \%$ for Oppliger (2013) formula and $<4 \%$ for Čech et al. (2008) formula. We appreciate that the reconstructed length of our specimen exceeded clearly $1000 \mathrm{~mm}$ (Table 1).

\section{CONCLUSIONS}

The first Lower Pliocene pike ever reported from Transylvania was unearthed in the South Racoş coal open pit, in the Braşov Basin (Baraolt sub-basin). The beginning of volcanism in the Harghita Mountains occurred around the Miocene/Pliocene boundary (Lexa et al., 2010; Panaiotu et al., 2012). Therefore, the first lacustrine environments took place in a region with input of large amounts of volcanoclastic rocks (László, 2005). At the first stage of the lake development, poorly oxygenated water dominated (Marincea et al., 1997), followed presumably by stratified waters with somewhat higher salinity in deeper areas, probably due to volcanic inputs, overlain by fresh water. In this lake, specific molluscs considered as Miocene survivors, as well as fish like the pike described herein, found convenient environments in the Early Pliocene. The pike found there enough prey, reaching a large size.

T a ble 1

Measurements [mm] of the fossil pike from South Racoş, compared with actual specimens

\begin{tabular}{|l|c|c|c|c|c|c|}
\hline & $\mathrm{RDL}$ & $\mathrm{REL}^{*}$ & $\mathrm{RDSH}$ & $\mathrm{REL}^{* *}$ & $\mathrm{TLC}$ & $\mathrm{O}$ \\
\hline Esox lucius 1 & 59.12 & 451.80 & 4.54 & 505.90 & 462.00 & Danube, Romania \\
\hline Esox lucius 2 & 62.30 & 474.00 & 4.88 & 543.20 & 446.00 & Danube, Romania \\
\hline Esox lucius 3 & 77.51 & 580.20 & 5.65 & 627.80 & 630.00 & Dumbrava Lake, Sibiu, Romania \\
\hline Esox lucius 4 & 58.73 & 449.10 & 3.92 & 437.80 & 455.00 & Danube, Romania \\
\hline Esox lucius 5 & 56.79 & 435.50 & 4.26 & 475.10 & 435.00 & Danube, Romania \\
\hline Fossil Esox sp. & 144.00 & 1044.30 & 11.90 & 1313.90 & - & Pliocene, Racoş \\
\hline
\end{tabular}

$\mathrm{RDL}$ - right dentary length measurement; REL* - body length reconstructed using Čech et al. (2008) formula RDSH - right dentary symphysial height; $\mathrm{REL}^{* *}$ - length reconstructed using Oppliger et al. (2013) formula; TLC - total length of the fish (actual measurement, for control); $\mathrm{O}$ - origin of the fish 
The Pliocene fish remains are extremely scarcely documented in Romania, however, in Transylvania, they are even rarer, as long as the Pliocene exposures are not numerous in this region.

Acknowledgements. We would like to thank both reviewers (Mr. D. Vasilyan and one anonymous reviewer) for their insightful comments on the paper, as their comments allowed us to improve the work. We also thank M. Čech for clarifying the issues regarding the size reconstruction formula, $\mathrm{O}$. Kovalchuk for the references he sent to us, and to our colleague A. Solomon for his kind help for taking and processing the photos of dentaries. Our late colleague and friend J. Gaudant helped one of us (V.A.C) much with references and advices at the early stage of research. This study is a tribute to his memory.

\section{REFERENCES}

Andreescu, I., Rădan, S., Rădan, M., 1987. Magnetobiostratigraphy of the middle-upper Neogene and Pleistocene deposits of Romania. Annales Institut Geologum Publici Hungariae, 70: 113-118.

Andreescu, I., Codrea, V., Enache, C., Lubenescu, V., Munteanu, T., Petculescu, A., Stiucă, E., Terzea, E., 2011. Reassessment of the Pliocene/Pleistocene (Neogene/Quaternary) boundary in the Dacian Basin (Eastern Peratethys), Romania. Oltenia, Studii şi comunicări, Ştiinţele Naturii, 27: 197-220.

Andreescu, I., Codrea, V., Lubenescu, V., Munteanu, T., Petculescu, A., Ştiucă, E., Terzea, E., 2013. New developments in the Upper Pliocene-Pleistocene Stratigraphic Units of the Dacian Basin (Eastern Paratethys), Romania. Quaternary International, 284: 15-19.

Bertoli, M., Manfrin, C., Bonzi, L.C., Pizzul, E., Pallavicini, A. 2016. First taxonomical analyses of pike populations (Esocidae, Esox) in Friuli Venezia Giulia (Northeast Italy). Annales, Seria Historia Naturalis, 26: 41-49.

Bry, C., 1996. Role of vegetation in the life cycle of pike. In: Pike, Biology and Exploitation (ed. J.F. Craig): 45-68. Chapman \& Hall, London.

Casselman, J.M., 1996. Age, growth and environmental requirements of pike. Fish and Fisheries Series, 19: 69-101.

Čech, M., Čech, P., Kubečka, J., Prchalová, M., Draštík, V., 2008 Size selectivity in summer and winter diets of great cormoran (Phalacrocorax carbo): does it reflect season-dependent difference in foraging efficiency. Waterbirds - The International Journal of Waterbird Biology, 31: 438-447.

Ciobanu, M., Zaharia, C., 1982. Contribuţii la studiul intiofaune Oligocene din Semifereastra Humorului (in Romanian). Anuarul Muzeului de Ştiinţe Naturale din Piatra Neamţ, Seria Geologie-Geografie, 5: 129-139.

Codrea, V., 2000. Rinoceri şi Tapiri Terţiari din România (in Romanian). Presa Universitară Clujeană, Cluj-Napoca.

Constantin, P., 1999. Oligocene-lowermost Miocene Fossi fish-faina (Teleostei) from Romanian East Carpathians. GeoEco-Marina, 4: 119-134

Crossman, E.J., Buss, K., 1965. Hybridization in the Family Esocidae. Journal of the Fisheries Research Board of Canada, 22: 1261-1292.

Crossman, B.J., 1996. Taxonomy and distribution. In: Pike, Biology and Exploitation (ed. J.F. Craig): 1-11. Chapman \& Hall. London.

Crossman, E.J., Meade, J.M., 1977. Artificial hybrids between Amur pike, Esox reichertii, and North American Esocids. Journal of the Fisheries Research Board of Canada, 34: 2338-2343.

Denys, G.P.J., Dettai, A., Persat, H., Hautecoeur, M., Keith, P. 2014. Morphological and molecular evidence of three species of pikes Esox spp. (Actinopterygii, Esocidae) in France, including the description of a new species. Comptes Rendus Biologies, 337: 521-534.

Fielitz, W., Seghedi, I., 2005. Late Miocene-Quaternary volcanism, tectonics and drainage system evolution in the East Carpathians, Romania. Tectonophysics, 410: 111-136.
Fink, W.L., 1981. Ontogeny and phylogeny of tooth attachments modes in Actinopterygian fishes. Journal of Morphology, 167: 167-184.

Gandolfi, A., Fontaneto, D., Mauro, N., Lucentini, L., 2015. Mitochondrial genome of Esox flaviae (Southern pike): announcement and comparison with other Esocidae. Mitochondrial DNA Part A: DNA Mapping, Sequencing, and Analysis, 27: 3037-3038.

Gaudant, J., 1979a. L'ichthyofaune tiglienne de Tegelen (Pays-Bas): signification paléoécologique et paléoclimatique. Scripta Geologica, 50: 1-16.

Gaudant, J., 1979b. Contribution à l'étude des Vertébrés oligocènes de Soulce (Canton du Jura). Eclogae Geologicae Helvetiae, 72: 871-895.

Grande, L., 1999. The first Esox (Esocidae: Teleostei) from the Eocene Green River Formation, and a brief review of Esocid fishes. Journal of Vertebrate Paleontology, 19: 271-292.

Grande, T., Laten, H., Lopez, J.A., 2004. Phylogenetic relationships of extant Esocid species (Teleostei: Salmoniformes) based on morphological and molecular characters. Copeia, 2004: 743-757.

Grosu, V.A., 1993. The Catalogue of the Molluscs from Romania Travaux du Muséum d'Histoire naturelle "Grigore Antipa", 33: 291-366.

Gruzdev, M.A., Vasiliev, E.D., 1988. Divergence of ordinary Esox lucius and Amur pike E. reicherti based on cranial features (in Russian). Journal of Ichthyology, 28: 567-578.

Jekelius, E., 1924. Zăcămintele de lignit din bazinul pliocenic din valea superioară a Oltului (Transilvania) (in Romanian). Institutul Geologic Român, Studii Tehnice şi Economice, 3: 1-34.

Jekelius, E., 1932. Die Molluskenfauna der dazischen Stufe des Beckens von Braşov. Memoriile Institutului Geologic Român, 2: $1-118$

Kottelat, M., Freyhof, J., 2007. Handbook of European Freshwater Fishes. Kottelat, Comol, Switzerland and Freyhof, Berlin.

Kovalchuk, O.M., Wilson, M.V.H., Grande, T., 2017. Neogene and Quaternary fossil pikes (Teleostei, Esocidae, Esox) of southeastern Europe, with a description of a new species of Esox from the early Pleistocene (Calabrian) of Nogaisk. Acta Palaeontologica Polonica, 62: 121-135.

Kusko, M., 1983. Zăcămîntul de lignit de la Sf. Gheorghe si pozitia lui stratigrafică în suita depozitelor pliocene ale bazinului intramontan al Tării Bîrsei (in Romanian). Studii şi Cercetări Geologice Geofizice, Geografice, 28: 125-131.

László, A., 1999. Studiul geologic al structurilor vulcanice din partea sudică a Masivului Harghita (in Romanian). Ph.D. thesis, University Babeş-Bolyai, Cluj-Napoca.

László, A., 2005. The post-Late Pontian paleogeographic evolution of the south Harghita Mountains area and the adjacent basins. Studia Universitatis Babeş-Bolyai, Geologia, 50: 27-40.

Lawler, G.H., 1960. A Mutant Pike, Esox lucius. Journal of the Fisheries Research Board of Canada, 17: 647-654. 
Lawler, G.H., 1966. A northern pike, Esox lucius, with an accessory fin. Journal of the Fisheries Research Board of Canada, 21: 1547.

Lexa, J., Seghedi, I., Németh, K., Szakács, A., Konečný, V., Pécskay, Z., Fülöp, A., Kovacs, M., 2010. Neogene-Quaternary Volcanic forms in the Carpathian-Pannonian Region: a review. Central European Journal of Geosciences, 2: 207-270.

Lubenescu, V., 2005. Fauna ponţiană relictă din Depresiunea Baraolt-Căpeni. Studii şi Cercetări de Geologie, 49/50: 61-74.

Lucentini, L., Puletti, M.E., Ricciolini, C., Gigliarelli, L., Fontaneto, D., Lanfaloni, L., Bilò, F., Natali, M., Panara, F., 2011. Molecular and phenotypic evidence of a new species of genus Esox (Esocidae, Esociformes, Actinopterygii): the southern pike, Esox flaviae. PLoS ONE 6: e25218. doi:10.1371/journal.pone.0025218

Mann, R.H.K., 1996. Fisheries und economics. In: Pike, Biology and Exploitation (ed. J.F. Craig): 219-241. Chapman \& Hall, London.

Marincea, S., Constantinescu, E., Ladriere, J., 1997. Relatively unoxidized vivianite in limnic coal from Capeni, Baraolt Basin, Romania. The Canadian Mineralogist, 35: 713-722.

Marinescu, F., Mărunţeanu, M., Papaianopol, I., Popescu, G., 1998. Tables with the correlation of the Neogene deposits in Romania. Romanian Journal of Stratigraphy, 78: 181-186.

Morales, A., Rosenlund, K., 1979. Fish bone measurements. An attempt to standardize the measuring of fish bones from archaeological sites. Steenstrupia, Copenhagen.

Newbrey, M.G., Wilson, M.V.H., Ashworth, A.C., 2008. Climate change and evolution of growth in Late Cretaceous to Recent North American Esociformes. Mesozoic Fishes - Homology and Phylogeny, 4: 311-350.

Nelson, G.J., 1972. Cephalic sensory canals, pitlines, and the classification of esocoid fishes, with notes on galaxiids and other teleosts. American Museum Novitates, 2492: 1-49.

Nelson, J.S., 2006. Fishes of the World. Fourth Edition. John Wiley \& Sons, Inc., New Jersey.

Nilsson, P.A., Skov, C., Farrell, J.M., 2008. Current and future directions for pike ecology and management: a summary and synthesis. Hydrobiologia, 601: 137-141.

Oppliger, J., 2013. La pêche au temps des lacustres sur les lacs de Neuchâtel et de Morat (Suisse): saisonnalité et stratégie du Néolithique moyen au Bronze final. Ph.D. thesis, University Genève.

Panaiotu, C.G., Vişan, M., Ţugui, A., Seghedi, I., Panaiotu, A.G., 2012. Palaeomagnetism of the South Harghita volcanic rocks of the East Carpathians: implications for tectonic rotations and palaeosecular variation in the past $5 \mathrm{Ma}$. Geophysical Journal International, 189: 369-382.

Papp, K., 1915. A Magyar birodalom vasérk- és kőszénkészlete. Franklin-Társulat Nyomdája.

Petrescu, I., Nicorici, E., Biţoianu, C., Ticleanu, N., Todros, C., lonescu, M., Mărgărit, G., Nicorici, M., Duşa, A., Pătruţoiu, I., Munteanu, A., Buda, A., 1987. Geologia zăcămintelor de cărbuni, 2 (in Romanian). Editura Tehnică

Raat, A.J.P., 1988. Synopsis of biological data on the northern pike Esox lucius, Linnaeus. 1758. FAO Fisheries Synopsis. 30 (Revision 2), Rome.

Rado, G., Pană, I., 1969. Dinţi de peşti neogeni din R. S. România (in Romanian). Analele Universităţii Bucureşti, seria Geologie, 18: $219-233$
Rădulescu, C., Samson, P.M., 1985. Pliocene and Pleistocene mammalian biostratigraphy in southeastern Transylvania (Romania). Travaux de l'Institut de Spéologie "Emile Racovitza", 24: 126-143.

Rădulescu, C., Samson, P.M., 2001. Biochronology and evolution of the Early Pliocene to the Early Pleistocene mammalian faunas of Romania. Bolletino della Società Paleontologica Italiana, 40: 285-291.

Rădulescu, C., Samson, P.M., Petculescu, A., Ştiucă, E., 2003. Pliocene Large Mammals of Romania/Grandes Mamiferos del Plioceno de Rumania. Coloquios de Paleontologia, Vol. Extended 1: 549-558

Savu, M.G., 1981. Grupul lacustru-vulcanogen de Baraolt (in Romanian). Dări de Seamă ale Şedinţelor Insitutului de Geologie şi Geofizică, 66: 213-226.

Savu, G.M., Lubenescu, V., Cismaru, G., 1978. Asupra vîrstei formaţiunii productive din bazinul Baraolt (in Romanian). Dări de Seamă ale Şedinţelor Institutului de Geologie şi Geofizică, 65: 157-168.

Săndulescu, M., 1984. Geotectonica României (in Romanian). Editura Tehnica, Bucureşti.

Săndulescu, M., Vasilescu, A., Popescu, A., Mureşan, M., Arghir-Drăgulescu, A., Bandrabur, T., 1968. Geological map of Romania 1:200000, 20 folio Odorhei.

Simionescu, I., 1930. Vertebratele pliocene de la Măluşteni (Covurlui) (in Romanian). Academia Română, Publicaţiunile Fondului Vasile Adamachi, Cultura Naională, Bucureşti 9: 83-151.

Skog, A., Vøllestad, L.A., Stenseth, N.C., Kasumyan, A., Jakobsen, K.S., 2014. Circumpolar phylogeography of the northern pike (Esox lucius) and its relationship to the Amur pike (E. reichertii), Frontiers in Zoology, 11, doi 10.1186/s12983-014-0067-8

Sytchevskaya, E.K. 1976. The Fossil Esocoid fishes of the USSR and Mongolia (in Russian). Nauka, Moskva.

Timm, A.L., Pierce, B.R., 2015. Vegetative substrates used by larval northern pike in Rainy and Kabetogama Lakes, Minnesota. Ecology of Freshwater Fish, 24: 225-233.

Toth, L., Codrea, V., Mol, D., 2010. The Racoş Mastodon: a complete skeleton of Anancus arvernensis. Quaternaire, Hors-série 3: 89-90.

Trelea, N., Saraiman, A., Voicu, M., 1977. Contribuţii la cunoaşterea faunei fosile de peşti din împrejurimile oraşului Gura Humorului (in Romanian). Analele Ştiinţifice ale Universităţii Al. I. Cuza, B, Geologie, 23: 49-54.

Trif, N., Vasilian, D., Popescu, A., 2016. Fossil fish remains from the Romanian of Podari, Southwest Romania. The first report Oltenia, Studii şi Comunicări Ştiinţele Naturii, Craiova, 32: 12-19.

Vasile, S., Ştiucă, E., Venczel, M., 2013. First find of ectothermic vertebrates from the Pleistocene "Copăceni Beds” (southern Romania), The 9th Romanian Symposium on Paleontology, Iaşi, Abstracts Book: 90.

Vasile, S., Petculescu, A., Venczel, M., 2015. Taxonomic diversity of the vertebrate assemblages from Copăceni - a new reference site for the Lower Pleistocene of the Dacian Basin, Romania, 13th Annual Meeting of the European Association of Vertebrate Palaeontologists Opole, Poland, Abstracts Book: 75.

Wilson, M.V.D., Brinkman, B., Neuman, A.G., 1992. Cretaceous Esocoidei (Teleostei): early radiation of the pikes in North American fresh waters. Journal of Paleontology, 66: 839-846. 